\title{
Estimation of Vitamin D levels in Women of Child bearing Age Group from Countryside: A Retrospective Observational Analytical Study
}

\section{Gokhale SG*, Kadrekar Meena and Gokhale Sankalp}

Department of Pediatrics and Neonatology, Rajhans Hospital and Research Center, Saphale, India

${ }^{*}$ Corresponding author: Gokhale SG, Department of Pediatrics and Neonatology, Rajhans Hospital and Research Center, Saphale, India, Tel: 091-800-779-8400; E-mail: rajhanssanjay@gmail.com

Received date: August 02, 2017; Accepted date: August 10, 2017; Published date: August 14, 2017

Citation: Gokhale SG, Meena K, Sankalp G. Estimation of Vitamin D levels in women of child bearing age group from countryside: A retrospective observational analytical study. Arch Med. 2017, 9:4

Copyright: (c) 2017 Gokhale SG, et al. This is an open-access article distributed under the terms of the Creative Commons Attribution License, which permits unrestricted use, distribution, and reproduction in any medium, provided the original author and source are credited.

\section{Letter to Editor}

In spite of abundant sunlight Vitamin-D deficiency is quite common in Middle East, Asian countries and India [1-3]. Many Indian studies are available recruiting mainly urban population. We went to determine status of Vitamin-D deficiency in local population. Here people are engaged in agricultural activities, no industrial pollution either. This is probably first study focusing on country side population.

We collected data about Vitamin-D levels in women of child bearing group from record section starting November 01, 2014 to December 31, 2016. Blood samples for Vitamin-D/ Hemoglobin estimations were collected by peripheral venepuncture. Hemoglobin was estimated by standard Drabkin's Reagent Method. Vitamin- D levels were estimated by LCMSMSLiquid Chromatography Tandem Mass Spectrometry [4]. This technique and machine measures serum vitamin-D levels beyond 4.2 monograms $/ \mathrm{ml}$. So values less than 4.2 nanograms/ml are read as UNDETECTABLE.

There were 451 participants; their age ranging from 18 years to 49 years (Figure $\mathbf{1}$ ).

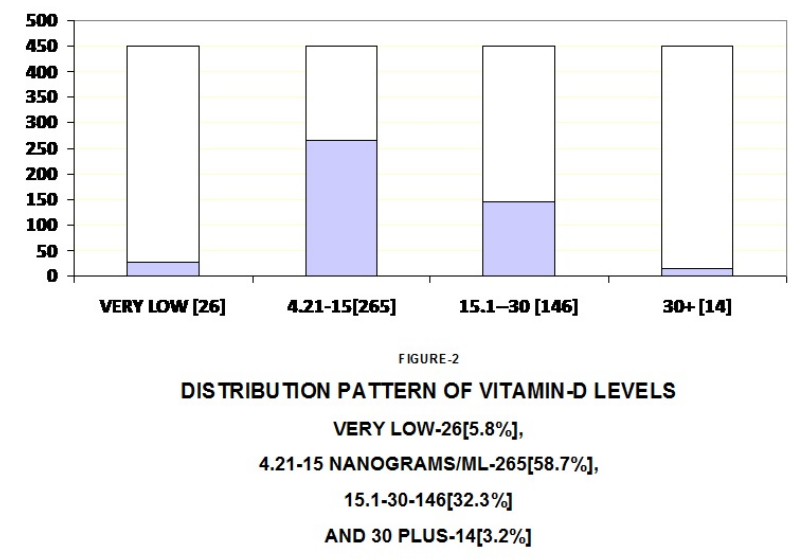

Figure 1: Distribution pattern of Vitamin D levels.
Only 14 Women had Vitamin-D levels more than $30 \mathrm{ng} / \mathrm{ml}$ [9/451=3.01\%]. Only 46 women [46/451=10.2\%] were holding office/indoor jobs; $405 / 451$ worked [89.8\%] in open fields/ busy in agricultural activities. 26 women [5.8\%] had very low or Undetectable Vitamin-D levels, 265 [58.7\%] had Vitamin-D levels more than 4.2 but less than 15 and 146 participants [32.3\%] had Vitamin-D levels more than 15, but less than 30 nanograms $/ \mathrm{ml}$. Only 14 women [3.2\%] had vitamin- d levels more than 30. 12 were unmarried and did not have children. One was married but non-pregnant 280/451 participants were first para, 155 had two babies, two had five children, and one was grand multipara [8 babies]. $37 / 451=8.12 \%$ had reasonable hemoglobin levels at or more than $12 \mathrm{gms} / \mathrm{dl}$. Only $3.01 \%$ showed vitamin-D more than $30 \mathrm{ng} / \mathrm{ml}$, or in other words $96.89 \%$ moms were vitamin-D deficient.

The problem of vitamin-D deficiency with abundant sunshine is multifaceted. Serum levels of Vitamin-D more than $30 \mathrm{ng} / \mathrm{ml}$ (to convert $\mathrm{ng} / \mathrm{ml}$ to $\mathrm{nmol} / \mathrm{ml}$ multiply by 2.5 ) are considered as 'normal'. Levels between 20 and $30 \mathrm{ng} / \mathrm{ml}$ are defined as 'insufficiency' and levels less than $20 \mathrm{ng} / \mathrm{ml}$ are defined as 'deficiency' [5]. Genetic factors like-Genetic variability of Vitamin-D Binding Protein and 'HIGH 24-25 HYDROXYLASE ENZYME ACTIVITY' seem to be operating [6-8]. Additionally women wear cultural dresses like Saree, Ghunghat or Burqa covering entire body with NO exposure to sunlight (Figure 2).

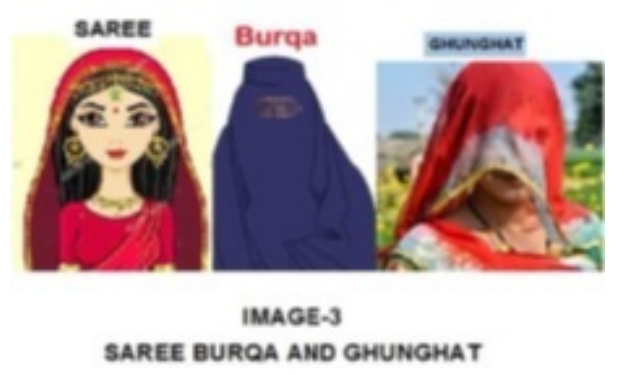

Figure 2: Saree, Burqa and Ghunghat.

Many people are not aware of benefits of Vitamin-D and sunlight. 
Could this be an adaptation, or an evolutionary change to prevent excessive levels of vitamin-D? Irrespective of etiology, the magnitude of the problem is significant and deserves implementation of preventive measures.

\section{References}

1. Nicolaidou P, Hatzistamatiou Z, Papadopoulou A, Kaleyias J (2006) Low Vitamin $D$ status in mother-Newborn pairs in Greece. Calcif Tissue Int 78: 337-342.

2. Harinarayan CV (2014) The multiple roles of Vitamin D. NFI Bull 35 : 3.

3. Paxton GA, Teale GR, Nowson CA, Mason RS, McGrath JJ, et al. (2013) Vitamin D and health in pregnancy, infants, children and adolescents in Australia and New Zealand: A position statement. Med J Aust 198: 142-143.
4. Holick MF (2011) The Vitamin D solution. Penguin Group First Plume Printing, pp: 149-151.

5. Zaidi S (2012) Power of Vitamin D. 1st Indian edn., STM Publishers, Mumbai, India, pp: 149-176.

6. Londhey V (2011) Vitamin D deficiency: Indian scenario. J Assoc Physicians India 59: 695-696.

7. Awumey EM, Mitra DA, Hollis BW (1998) Vitamin D metabolism is altered in Asian Indians in the southern United States: A clinical research center study. J Clin Endocrinol Metab 83: 169-173.

8. Fu L, Yun F, Oczak M (2009) Common genetic variants of the vitamin $\mathrm{D}$ binding protein (DBP) predict differences in response of serum 25-hydroxyvitamin- $\mathrm{D}[25(\mathrm{OH})]$ to vitamin $D$ supplementation. Clin Biochem 42: 1174-1177. 